\title{
BUILDING ECOLOGICAL NETWORKS IN SLOVAKIA AND POLAND
}

\author{
ZITA IZAKOVIČOVÁ ${ }^{1}$, MAŁGORZATA ŚWIĄDER ${ }^{2}$ \\ ${ }^{1}$ Institute of Landscape Ecology, Slovak Academy of Sciences, Štefánikova 3, 81499 Bratislava, Slovak Republic; \\ e-mail: zita.izakovicova@savba.sk \\ ${ }^{2}$ Department of Spatial Economy, Wrocław University of Environmental and Life Sciences, pl. Grunwaldzki 24 A, \\ Wroclaw, Poland; e-mail: malgorzata.swiader@upwr.edu.pl
}

\begin{abstract}
Izakovičová Z., Świąder M.: Building ecological networks in Slovakia and Poland. Ekológia (Bratislava), Vol. 36, No. 4, p. 303-322, 2017.

The paper is aimed at evaluating the creation of territorial systems of ecological stability in two neighbouring countries - Slovakia and Poland. The paper evaluates various initiatives and approaches and their positives and negatives. It represents methodical approaches to the creation of territorial systems of ecological stability as well as the legal provision of ecological networks in both countries. The outcome of the evaluation is the proposal for the necessary measures to improve the situation.
\end{abstract}

Key words: ecological networks, territorial system of ecological stability, NATURA 2020, biocentre, biocorridor.

\section{Introduction}

The concept of ecological networks arose as a response to fragmentation and intensification of land use about 30 years ago. It is a basic tool for biodiversity protection as well as nature and landscape conservation. The ecological network is a spatially coherent and functional system that represents Europe's best-preserved regions in terms of biodiversity and landscape (Liro, 1998), planned and managed in order to preserve or restore ecological functions, simultaneously constituting a form of biodiversity protection, whilst ensuring the sustainable use of natural resources (Jongman, 2008). Gradually, several initiatives for creating ecological networks have been established. On an international level, approximately 150 environmental programmes creating ecological networks were identified, out of which around 50 were developed in Europe. The most significant are the following: PAEN Central and Eastern Europe, Regional Cross-Border Networks Alpine, Carpathian Ecological Network, Caucasus, European Coastal and Marine Ecological Network - Western Europe, Volga-Ural European Ecological Network, Green Belts (European green skeleton), The Programme of the National Reserve System in Australia, Ecological Corridors - America and others. On a European level, we can include the creation of the European Ecological Network (EECONET) as one of the most significant initia- 
tives (Jongman, 1996). Its aim was to create an integrated system of protected territories in European countries based on generally applicable international criteria and standards. It consists of several national ecological networks (NECONETs) (Hüse et al., 2016). The EECONET was the output of The Convention on Biological Diversity (CBD) (Louka, 2004).

The CBD initiated in Rio de Janeiro on 5 June 1992 changed the way of protecting valuable natural resources from the diffuse individual actions for an integrated, sustainable protection of nature. The change in approach was related to the low efficiency of the environmental measurement taken to minimise the extinction of species and the destruction or reshaping of natural systems. Therefore, the convention has three main targets: (1) the preservation of biodiversity (diversity of living organisms on Earth), (2) the sustainable use of components of biodiversity and (3) the fair and equitable sharing of benefits arising from the utilisation of genetic resources. Thus, each signatory government is obliged to (1) cooperate with other governments and international organisations to protect and diversify the use of biodiversity; (2) develop environmental protection strategies and include the protection of biodiversity into national decision-making process, cross-cutting plans, programmes and policies; (3) determine and keep under observation the biodiversity and the factors that influence it; (4) protection of biodiversity through activity such as the signify and management of protected areas, protection of ecosystems and natural habitats, promoting rationally environmental and sustainable development in areas adjacent to protected areas, restoration of degraded ecosystems and support in the reproduction of endangered species or taking additional protective measures (Council 93/626/EEC). The approach expressed within the CBD has been reflected in the Pan-European strategy for biological and landscape diversity elaborated in 1995 at the Ministerial Conference 'Environment for Europe' held in Sofia (Liro, 1998).

In 1995, after ministerial conference, the Pan-European Biological and Landscape Diversity Strategy (PEBLDS) has been accepted, which assumed the development of an EECONET called Pan-European Ecological Network (PEEN). The PEBLDS was a visionary approach for the protection of biodiversity in Europe (Van der Sluis et al., 2011). PEEN concept assumed that the ecological network consists of elements such as core areas, corridors and buffer zones. The core areas are understood as zones of high natural values for the conservation of landscapes, species and habitats. The criteria for identification of core areas are not homogeneous. It does mean that these areas may be categorised into two main types: institutional natural protected areas and areas with characteristic suitable for the survival of certain species (i.e. vegetation, size and spatial configuration) (De Montis et al., 2016). Thus, there are nodes of a water peatland, forest, steppe, mosaic and so on, depending on the type of accompanying ecosystems (Chmielewski, 2009). Corridors are physical connection between core areas that allow self-regulation of ecosystems by species spreading. These corridors could be distinguished from each other by the following specification: structure (continuous or discontinuous - stepping stones), function (migration, commuting and dispersal), characteristic (i.e. naturalness and biopermeability) (De Montis et al., 2016). Buffer zones are described as surrounding core areas and connecting elements that protect network elements against exogenous interference coming from the adjacent areas.

Regarding to the implementation of ecological network, it can be characterised by the following approaches: physiographic (focused on maintaining and strengthening the differ- 
ent ecosystems of spatial structure), functional (centred on ecological processes management) and planning (oriented to the multifunctional planning perspective). That approach comes from green infrastructure concept implemented by the European Environment Agency, which assumes complex and wide-ranging ecological landscape planning by taking into account the ecological networks, environmental features and biodiversity. Therefore, the ecological network is assigned an exceptional importance. In particular, it emphasises the important role of functionally and ecologically integrated landscape planning (De Montis et al., 2016).

The aim of the paper is to introduce and evaluate the concept of 'ecological networks' in two neighbouring countries by comparing their similarities, specifics, strengths and weaknesses and assessing the effectiveness of nature and landscape conservation. The concept of ecological network for Slovakia and Poland was developed in the years 1995-1996 in the framework of the research project National Nature Plan (NNP) in the framework of the European Programme of the International Union for Conservation of Nature. In this project, apart from Slovakia and Poland, Hungary and the Czech Republic also participated. The basis for the creation of a NECONET was the adoption of uniform guidelines and methodology of an EECONET concept (Liro, 1998).

\section{Methods}

The basic method used for the evaluation was method of document analysis and comparative analysis. Whilst analysing, two basic types of documents were analysed:

- Analyses of legislative instruments aimed at the creation of ecological networks in individual countries.

- Analysis of methodological procedures, concepts and strategic documents in the field of realisation of ecological networks.

In both countries, document analyses were realised separately and SWOT analysis was performed in each country. Subsequently, a comparative analysis was carried out in the approaches of the two countries; the positive and negative aspects in each country were assessed and measures to improve the situation were established.

\section{Results}

\section{Ecological Network in Slovakia}

The beginnings of the initiation of the TSES (territorial system of ecological stability) created in Slovakia can be dated to 1985, when a map of the TSES was included within the Ecological General plan of the Slovak Republic (Miklós et al., 1985). The initial TSES concept was developed in cooperation with the Czech School (Lőw et al., 1984). After the dissolution of the Czechoslovak Republic, these schools were divided and the TSES began to develop independently in each country.

In the Slovak Republic, the concept of 'ecological networks' was adopted as a concept of 'the territorial system of ecological stability' (TSES) by Decision of the Government of the SR No. 394 of 23 July 1991. In the Slovak Republic, the LANDEP methodology was the theoretical and methodical basis of the concept of the TSES creation and was elaborated in the Institute of Landscape Ecology of the Slovak Academy of Sciences, Bratislava (Ružička, Miklós, 1982). The TSES concept was built on a geosystem approach to the landscape. 
The concrete elaboration of the TSES projects started in 1991, when a TSES concept was developed and approved. The creation of the TSES projects in Slovakia were carried out on a 'top-bottom' basis - from the General Plan of the supraregional territorial system of ecological stability (STSES) through to the regional territorial system of ecological stability (RTSES) to the local territorial system of ecological stability (LTSES).

In 1992, the STSES was elaborated, which reflects the basic framework of spatial ecological stability in Slovak territory. It represents a spatial arrangement of the most important ecologically preserved natural territories (especially forests, wetlands, rocks, vegetation stands along water courses, etc.), and it specifies the relationship and significance of the ecologically stable territories in Slovakia, connecting them to the European system of ecologically stable territories, thereby creating an important document for the strategy of protecting ecological stability, biodiversity and genetic resources in the Slovak Republic (Miklós, 1991). STSES was developed on a scale of 1: 500,000 and 1:200,000 and was approved on 27 April 1992 by the Government Resolution No. 319. In 1996, following the STSES, a draft of a national ecological network known as NECONET was created.

Between the years 1993 and 1995, individual RTSES was gradually processed. RTSES were elaborated for all 38 former districts of Slovakia. Their mission is to provide conditions for the conservation of species diversity of the natural gene pool of organisms in a particular region. RTSES were processed on a scale of 1:50,000 and 1:25,000. They create a basic landscape-ecological base for the elaboration of spatial planning documents of the regions and also form the basis for the other sectors and their documentation (nature protection, territorial development, land consolidation projects, forest management plans, etc.).

Following the elaboration of regional territorial systems, the elaboration of the LTSES began. The local level ensures the specific from the functional perspective crucial conditions for the conservation of species diversity of the natural gene pool. It is based on a regional level, which is detailed to the level of the specific localisation of the landscape elements. LTSES represents a concrete basis for the implementation of projects. Local territorial systems are mostly processed on a scale of $1: 10,000$ or 1:5,000. They create a landscape-ecological base for the elaboration of municipal plans, settlement zones and land consolidation projects (Reháčková, Pauditšová, 2008).

At the present time, updating of STSES and RTSES is running in the Slovak Republic. The requirement for the update of STSES has emerged from the need to harmonise the national and international network of protected levels. At the same time, the model of representative geo-ecosystems (REPGES) in Slovakia was incorporated into the creation of the TSES (Miklós et al., 2006).

\section{Legal aspects of Ecological Network in Slovakia}

The real importance of the TSES is ensured by legal support in the following acts (Izakovičová, Miklós, 2010):

a. Act on Nature and Landscape Protection 284/1994 and 543/2002 Z.z.: there is the basic definition of TSES, European network Natura 2000 and its determination as basic document for different planning. 
b. Act on Territorial Planning and Construction Order, amendments 262/1992 Zb. and 237/2000 Z.z. defines that the elements of TSES are obligatory regulative on all level of territorial plans.

c. Act on Land Arrangement and Land Ownership 331/1991 Zb. and its amendment 549/2004 Z.z. defines that the TSES is an obligatory basement and part of each Land Arrangement Project; moreover, the need for improving the TSES function might be accepted as a legal cause for the enactment of the land arrangement procedure. In the land arrangement project, the elements of the TSES and important landscape elements are considered as common arrangement.

d. Act on Environmental Impact Assessment 127/1994 Z.z. and 24/2006 Z.z. defines that TSES is an obligatory object of impact assessment.

e. The Water Act 364/2004 Z.z. (based on Water Framework Directive 2000/60 of EP and EC) forces the utilisation of the water-protecting function of TSES with the coordination of water management tasks.

f. The new act on Flood Protection (coming into force by 1 February, 2010) enacts that the long-term management plan of watersheds should also project the TSES, important landscape elements and the eco-stabilising measures. Projecting TSES became the subject of the authorisation according to the Act on Authorised Architects 138/1992 Zb. and its later amendments.

For an effective implementation of the TSES, the determination of the position of the TSES elements has decisive importance in the spatial planning documentations. In the basic act on territorial planning, the elements of the TSES are defined as obligatory regulatives on all levels of planning process (Pauditšová, 2010). In fact, the set of ecological regulatives might be quite wide ranged and demanding. Many of the basement ecological data were not designed for direct use in spatial planning processes. Therefore, such basement materials need to be revaluated and transformed into the form of regulative (Muchová, Petrovič, 2010). The processing of those data and regulatives is the part of the step of territorial planning named as 'Surveys and analyses' in territorial planning documentations supported by Amendment 237/2000 Z. z. to the Act 50/1976 Zb. on territorial planning and building order. Later, the regulatives can also be reflected in other kinds of project documentations (land records, hydroecological plans, forestry plans, etc.).

\section{Ecological Network designation methods in Slovakia}

TSES is a concise method based on the landscape ecological research that modified the ideas of ecological networks towards integrated management of optimum organisation and utilisation of the landscape as a whole. TSES was developed as a routine procedure to the spatial planning practices very early, since 1984, together with the method of landscape-ecological planning LANDEP (Ružička, Miklós, 1982). After the political changes in 1990, TSES has been implemented as one of the basic idea to the act on nature and landscape protection. During 1990-1992 within former Slovak Commission for Environment, first legislative basis for TSES was prepared. The concept of territorial system of ecological stability has been approved by the Government in the year 1992. Here, TSES was defined as a territorial model 
being constructed by optimal structure of biocentres, biocorridors, interactive elements and ecologically stabilising measures. The concept defined basic principles, the basic elements, selection criteria (such as degree of representativeness, landscape-ecological importance, size, location and functionality) and hierarchical levels of TSES and put attention on necessity to create legislative and economical conditions for TSES realisation. The procedure for the TSES contains the following basic actions (Izakovičová et al., 2000):

a. Delineation of main elements of the TSES: biocentres, biocorridors and interactive elements. These elements compose the frame of an ecological network. As biocentres should be delineated those biotopes which serves as the basis for food, shelter and site for reproduction, as the biocorridors and interactive elements should be projected chains of biotopes which brake the isolation and ensure the migration and interaction as well as the spatial ecological stability of the landscape.

b. Definition and proposal of the so-called eco-stabilising measures, which should fulfil different practical ecological function such as soil and water protection, microclimatic, hygienic, aesthetic and other functions. Amongst these, the agro-technical, agro-ameliorative and forest management measures might be underlined. Proposals of eco-stabilising measures consist of

- Proposals for location of new eco-stabilising elements - particularly localisation of groups and non-forest vegetation belts. The aim of this set of proposals is the improvement of overall ecological spatial stability. Proposals for eco-stabilising measures have to be done with respect to the improvement of water-bearing capacity of landscape, decrease in runoff from landscape, increase in natural purification of landscape, measures for anti-erosion protection in a landscape and so on.

- Proposals for ecologically optimal land use of agricultural landscape - it represents proposals for agro-technical, agro-chemical and agro-ameliorative proposals that come out from an analysis of natural conditions (abiocomplexes) of the given territory.

- Proposals for eco-stabilising measures within forest ecosystems - particularly change in species, diversity securing, revitalisation of damaged forest ecosystems and specification of delicate ways of forestry techniques.

- Proposals for eco-stabilising measures within urbanised areas - these means proposals for the improvement of overall quality of environment.

The aim of these proposals is the improvement of spatial stability of territory and the enhancement of the environmental quality of the countryside as a whole.

c. Proposals for elimination of stress factors, with the focus on mitigation of effect of stress factors in a landscape. These consist of

- Proposals for new technological measures with focus on decrease in inorganic elements. This comes out from the proposals for the reduction of air pollutants, soil pollution, pollution of water resources and elimination of noise sources as well.

- Proposals for revitalisation of environmentally devastated areas - these are represented by proposals for activation of individual features of environment and natural resources.

- Proposals for reduction of effect of physical barriers of anthropogenic elements of 
landscape on TSES elements. It means proposals for passing the barriers, such as locations where ecological corridors are cut by roads, which cannot be closed, it is necessary to build tunnels, underpasses or other types of ecoducts with focus on the most delicate species of biota that uses the corridors.

The aim of these proposals is the elimination of factors that threat individual elements of TSES, natural resources and environment. By combining three groups of actions, the TSES becomes a whole-space covering - 'territorial' - system, what differs from 'classic' ecological network concepts, which mostly concentrate only to biocentres and biocorridors.

In Slovakia, according to the STSES, 87 biocentres of supraregional importance have been allocated, occupying an area of 271,600 ha, which represents $5.54 \%$ of Slovakia. Eight biocentres have been identified as unique and 79 as representative. The STSES also identified biocorridors of supraregional, provincial and biospheric significance at a length of 2,660 km, determined on the basis of historical and current migratory routes of flora and fauna (Fig. 1). In addition, ecologically important units and areas that represent the wider environment (the protection zone) of the supraregional biocentres have also been identified within the STSES. They are formed of more stable forest areas or meadow-pastureland areas.

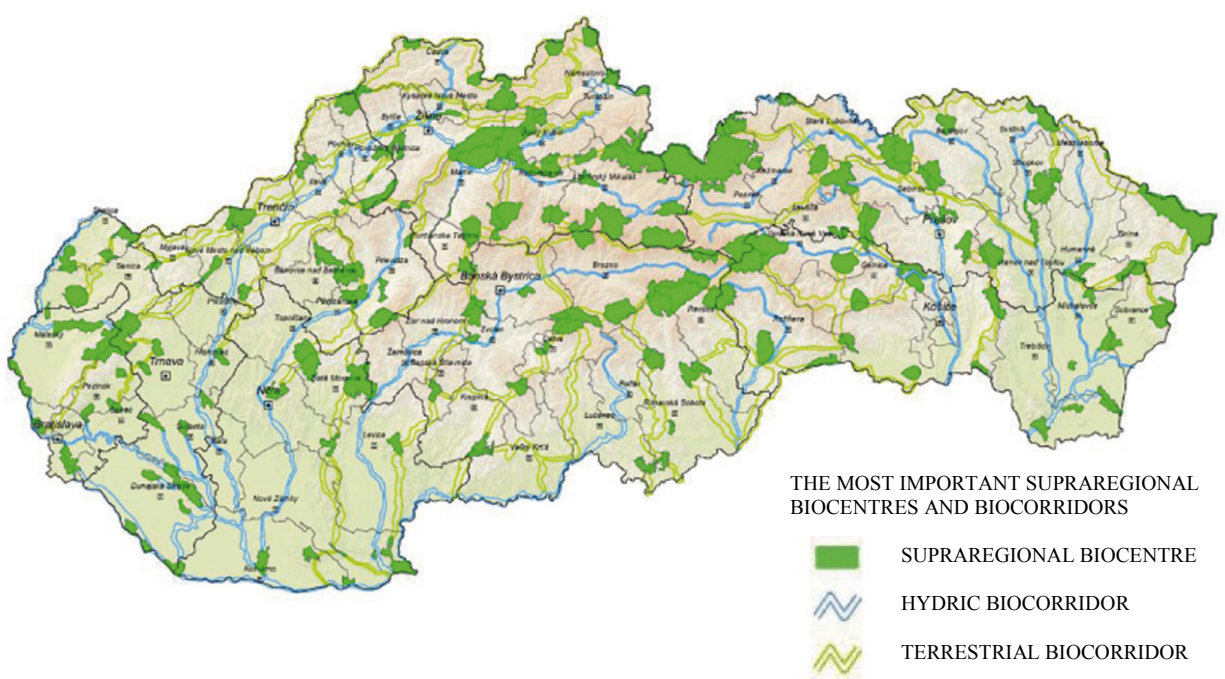

Fig. 1. Territorial system of ecological stability in Slovakia. Data source: ŠOP SR Banská Bystrica, 2000.Compiled: SAŽP, 2014. Basic map backround: 1:500 000.

In Poland as well as Slovakia, the ecological networks (ECONET) initiative has been developed. For both Poland and Slovakia, it was not officially accepted in strategic documents. It was developed instead on a volunteer basis. The NECONET proposal was developed by nongovernmental organizations (NGOs). The NECONET proposal was based on the concept of building an EECONET based on the Dutch concept of creating ecological networks. 
The main aim of EECONET was

- Identification of core areas (core areas) for the conservation of habitats and species.

- Identification of biocorridors (corridors) that ensure the migration and interconnection between natural ecosystems.

- $\quad$ Revitalising and creating new natural elements.

- Specification of buffer zones to protect the 'core areas and corridors' from adverse impacts.

It represents a network of important areas, especially protected areas, which are vital for the conservation of gene pool and biodiversity. It is based on the delimitation of nuclear sites (similar to biocentres within TSES), ecological corridors (similar to biocorridors within the TSES) and the territories of the development of natural elements of the European and national importance. Its aim is to create an integrated system of protected areas and potentially valuable territories in individual European countries according to the international criteria and standards (Miklós, 1991).

As in other EU countries, a coherent European network of specially protected areas - NATURA 2000 - is being created in Slovakia and consists of two types of sites:

Special protection area (SPAs) are sites that are declared based on the criteria laid down in the Council Directive No. 79/409 / EHS from 2 April 1979 about the conservation of wild birds for the purpose of protecting and ensuring a favourable status of selected vulnerable bird species. There are 341 wild bird species in the SR. From a European perspective, 81 of them are classed as rare species. In Slovakia, there are currently 41 SPAs declared with a total area of $1,282,811$ ha, which represents $26.16 \%$ of Slovakia. The overlap of the SPAs with current protected areas is $55.15 \%$. The boundaries of many SPAs are not delimited optimally, and many of them also occupy agrobiocenoses: it is very difficult to harmonise agricultural production with nature conservation.

Sites of Community Importance (SCIs) - sites proposed based on the criteria set out in the Council Directive No. 92/43/EHS on the conservation of habitats, wild fauna and flora in order to protect, maintain or improve the status of habitats, plant and animal species of European significance. There are currently 473 SCIs declared with a total area of 584,353 ha, which represents $11.9 \%$ of Slovakia. The overlap of the proposed SCIs with current protected areas is $86 \%$.

In 2006, based on the REPGES, a concept of the nature protection in the Slovak republic was elaborated (Miklós et al., 2006). The list of types of REPGES should serve as an ecologically based systematic framework for new protected areas (according to the analysis of insufficiently protected REPGES) designations, as well as for methodical proposals of biocentres of the TSES on the regional level. Geo-ecosystems are particular objects and bearing elements of geo-ecodiversity. However, the definition of criteria for the determination of representative geo-ecosystems is a very complex problem. Individual types of the REPGES in the Slovak Republic have been determined based on the following (Miklós et al., 2006):

- zonal (bio-climatic) conditions, most often represented by the vegetation zones in a landscape. They are characterised according to the bio-conditions, which are in their complexity expressed in 9 zones of potential vegetation,

- azonal conditions, primarily quaternary geological ground and relief, secondary soils and levels of underground water, which are divided into 37 types. In a real landscape, these conditions are expressed in a very complex way and cannot be separated. The zonal con- 
ditions in a region cannot be changed at all, whilst azonal - soils, water forms and relief - can, through investment of a certain amount of energy, be partially changed or affected.

In the Slovak Republic, by territorial synthesis, azonal and zonal conditions have been determined altogether 120 potential REPGES types. The REPGES types have a character of potential geo-ecosystems, because they have been determined based on the abiotic conditions that represent a certain potential for the development of geo-ecosystems and are characterised based on the potential vegetation. Many potential REPGES have been considerably changed, when their potential vegetation has been replaced by agro-associations, urban ecosystems or eventually secondary forest.

Additionally, we have a national network of protected areas in the Slovak Republic, which has been increasing gradually since 1949. The protection of nature and landscape is ensured under Act No. 543/2002 Coll. on Nature and Landscape Protection. According to this law, there are currently 9 national parks in Slovakia, occupying $6.48 \%$ of the SR, and 14 protected landscape areas, which represent $10.66 \%$ of the Slovak Republic. Protection zones that occupy $5.51 \%$ of the SR are declared in the vicinity of national parks. Protected areas altogether with protection zones occupy $22.65 \%$ of Slovakia. Apart from the 'large-scale protected areas' (National Parks and Protected Landscape Areas), there are also 1,108 small protected areas (protected areas, nature reserves, national nature reserves, natural monuments, national natural monuments and protected landscape features).

Beside these protected areas declared according to Act No. 543/2002 Coll. on Nature and Landscape Protection, there are also territories of international importance have been declared, namely, 4 UNESCO biosphere reserves (Polana, Slovenský kras, Východné Karpaty and Tatry), 2 territories that have been awarded the European Diploma of Protected Areas (National Nature Reserve Dobročský prales, National Park Poloniny), 2 international territories listed by the World Natural Heritage (The Caves of Aggtelek Karst and Slovak Karst, Primeval Beech Forests of the Carpathians) and 17 wetlands (Ramsar Sites).

It goes to show that whilst a system of protected areas may be relatively dense and extensive - both in size and proportion - it is not necessarily representative. Many protected areas overlap and have different degrees of protection. Their borders are often not sufficiently matched. Protected areas are not spread evenly across the whole of Slovakia, but they are linked to certain areas, especially on the protectively attractive landscape structures. However, from the perspective of biodiversity, these shortages need to be eliminated and we need to ensure the protection of less-attractive landscape areas such as basins and lowlands. If we want to ensure the effective protection of biodiversity and the stability of the landscape, it is necessary to ensure an effective system of protected areas linked to a functional territorial system of ecological stability.

Currently, the European Union has launched another initiative - to build a green infrastructure, whereby the aspect of the efficient use of ecosystem services and utilities markedly dominates.

\section{Ecological Network in Poland}

This concept was the first in Europe, which could be called coherent network of protected areas. Aims to determining the country and its regions ESOCh were to (1) stabilise climatic 
conditions, (2) maintain a natural hydrological regime and hydrological, (3) provide favourable conditions for the functioning of the landscape ecosystems units and species migration in the landscape and (4) provide the conditions for the production of healthy food and the development of tourism and recreation. The main network cores were national parks, landscape parks, nature reserves, protected landscape areas and larger complexes of forest and meadow with subsistence or a special ecological significance, interrelated by special environmental corridors. The consistent implementation of the concept led to cover $30 \%$ of the Polish country area by this network (at the end of 2013, this network consisted of 23 national parks, 1,481 nature reserves, 121 landscape parks and 386 protected landscape areas) (Chmielewski, Kolejko, 2014). The concept emphasised the need for the creation and protection of ecological corridors (bio-corridors) and ensured better conditions for the functioning of natural systems of a country. Polish approach became interested for Dutch researchers, who in 1991 elaborated the concept of the EECONET (Chmielewski, Kolejko, 2014). The Poland has actively participated in the activities for the establishment of an EECONET. In 1996, Poland ratified the convention on the diversity, and in the framework of the research project, NNP developed network for the area called ECONET-PL, which was representing in that times a completely new structure not having any legitimacy. Despite the lack of a legal relationship, the network has been included in the strategy of spatial development of the country as a guideline for policy planning (Liro, 1998).

The approach of ECONET-PL was similar to the idea of ESOCh created in the 1970s. Both concepts united assumptions regarding to (1) the continuity of the system through establishing ecological corridors linking protected areas, (2) the use of stepped regime of protection, which have to surround areas of highest natural areas by buffers with lower values and a lesser degree of protection, and (3) the protection and the principle of maintaining sustainable areas prone to the risks in the development plans. The implementation of ESOCh concept was problematic because of the lack of synchronisation and integration of the system in the border areas of all Polish regions. Although, in the 1970s, ESOCh has not been implemented in all regions of the Poland, existing and planned protected areas from it became the basis for an EECONET (Liro, 1998).

After the Polish accession to the European Union in 2004, the project ECONET-PL has not been officially approved by the Ministry of the Environment, which was associated with the adoption of the Natura 2000 system (Gerlée, 2010). This network consists of two types of protected areas: Special Areas of Conservation (SAC) and SPA. Initially, the network concept has been criticised because of the lack of consistency - was in fact a collection of isolated ecological refuges (bio-centres). Therefore, in 2003, it has been suggested to supplement it with the ecological system of bio-corridors connecting protected areas (Wojciechowski, 2004). Despite the fact that the network ECONET-PL has not received acceptance and legitimacy, this concept appears, is still presented in studies of planning (Szulczewska, 2004) and is used to develop other systems of nature conservation at national and regional levels (Wojciechowski, 2004). Furthermore, 46\% of the country area was included to ecological network project, which contained the 78 core areas $(30 \%$ of the country) connected by a network of ecological corridors (Monitor Polski, 2001). 
Nowadays, in Poland, element of ecological network concept are introduced into the legal terms in planning documents at different levels of governance. Studies at national and regional levels have a character of guidelines for spatial planning, and those at the local level have a character of guidelines for operational planning (Pawłat-Zawrzykraj, Brzank, 2015). This means that documents of higher levels (national unattended and regional) are for general guidance. Thus, the crucial for effective implementation of the idea of ecological network are local planning documents, which allow more specific coverage, course and borders of ecological corridors (Pawłat-Zawrzykraj, Brzank, 2015).

The most recent document of national spatial policy is the National Spatial Development Concept 2030 (pol. Koncepcja Przestrzennego Zagospodarowania Kraju 2030 - KPZK 2030), approved by the Polish Government in December 2011. That conception is the most important strategy document on spatial development of the country. The document sets out a vision, goals and directions of country land management and indicates the principles of human activities, including respect for the environment, the landscape and culture. One of the main objectives of the strategy was the development and carrying for spatial structures in support of achieving and maintaining a high-quality environment and landscape that aimed at overcoming (1) lack of hierarchy of plans, (2) lack of plans to protect natural areas and (3) lack of physiographic analysis, which being one of the causes of over-exploitation of natural environment. Amongst these, the following activities can be mentioned: the integration of activities in the operation of a coherent ecological network of the country, being a base for the protection of the most valuable natural resources and landscape. Polish ecological network is to be established by integrating areas: ESOCh (there exist need to extend it), Natura 2000 network, PEEN, network of biosphere reserves of the United Nations Educational, Scientific and Cultural Organization (UNESCO) (which also have to be extended). The concept also envisages the implementation of ecological corridors to Polish law, especially into urban planning, which are one of the basic elements of ecological network (Ministry of Development, 2011), which since 1996 has not taken place (Bernatek, 2011).

Currently, Polish legislation includes only official definition of ecological corridor contained in the Act on the Protection of Nature (pol. Ustawa o ochronie przyrody), which defines it as an area that allows the migration of plants, animals or fungi. The Act also provides that the function of ecological corridor can serve as a protected landscape area (hence, approximately $60 \%$ of the corridors coincide with the areas protected by law - Bernatek, 2011), which does not mean that the ecological corridor was approved as a separate legal form of protection. Despite this, the Act on the Protection of Nature provides the ability to create protected landscape areas. The need to protect ecological corridors is also emphasised in The National Strategy for the Conservation and Sustainable Use of Biodiversity (pol. Krajowa strategia ochrony i umiarkowanego użytkowania różnorodności biologicznej), which is the result of ratification of the CBD from Rio de Janeiro by Poland. The strategy, as one of the operational activities, established to restore and protect the network of ecological corridors (forest, river and others) to ensure the exchange of genes between different 
local populations. Furthermore, since the signing of the Accession Treaty in 2004, Poland has to protect the ecological corridors in accordance with the provisions of the Habitats Directive (Gerlée, 2010).

The definition of the ecological corridor also appears as part of the Regulation of the Minister of Environment dated 28 September 2004 on the species of wild animals under protection, where next to the ways of wild species protection, such as providing patency courses that are routes of migration as wildlife crossings constructed over and under public roads and railway lines, which allow migration and also development and maintenance of ecological corridors (Rozenau-Rybowicz, Baranowska-Janota, 2007). Despite of this, the official definition of ecological corridors system and ecological network in the Polish legislation does not exist (Pawłat-Zawrzykraj, Brzank, 2013).

Despite the lack of legitimacy of the ecological network in Poland, it is assumed that the development of an integrated, coherent ecological network of the country will allow the achievement and maintenance of high-quality natural environment and landscape values, as well as prevention against natural space fragmentation. The lack of compliance in the urban planning in Poland ${ }^{1 *}$ at each level of governance is not conducive to achieve this goal. Despite the fact that the corridors - which are part of the ecological network - are included in the country and regional strategies, it is not sure what part of these arrangements will be in the documents at lowest level, that is, in the study of conditions and directions of spatial development or local spatial development plan, which have the most important role (Pawłat-Zawrzykraj, Brzank, 2013). This occurrence is associated with fact that ecological corridors that do not coincide with the legal form of protection are often not taken into adequate attention into the local spatial development plans (Chmielewski, 2009). Therefore, the current lack of direct including of ecological corridors (RozenauRybowicz, Baranowska-Janota, 2007) and the ecological network in the Polish law may enable the proper functioning of ecological connectivity, ecosystem services and other issues of contemporary nature and landscape protection (Pawłat-Zawrzykraj, Brzank, 2013). Despite the obligations imposed on Poland (in case of ecological network and its elements), there is still visible lack of legitimacy of these structures. No legislation could have the same negative impact on the formation of these spatial structures that support the

\footnotetext{
"Planning system in Poland (according to the provisions of the Act of 27 March 2003 on spatial planning and development; pol. Ustawa o planowaniu z zagospodarowaniu przestrzennym) is being implemented in three administrative levels, which is associated with the hierarchy of jurisdiction. Thus, the decisions taken at each administrative level should support the decisions of the parent level, which should be given priority implementation. There exists a vertical procedure, that is,

1. National level, at this stage arise primarily study works, conceptual programmes of strategic character. At this level, The concept of National Spatial Development (pol. Koncepcja Przestrzennego Zagospodarowania Kraju) is created. 2. Regional level, where documents also are strategic guidelines, which takes into account the guidelines set out at national level. The works are conducted for each of the 16 regions (pol. województwo), for which the study of conditions and directions of spatial development of the region are prepared (pol. studium uwarunkowań $i$ kierunków zagospodarowania przestrzennego województwa).

3. The local level, at this level, the study of conditions and directions of spatial development of municipality are prepared (pol. studium uwarunkowań i kierunków zagospodarowania przestrzenengo gminy), which is the basis for creating local development - master plan (pol. miejscowy plan zagospodarowania przestrzennego). The plan is an act of local law, which means that it has an obligatory, executive character, not a facultative-consultancy character (Kwartnik-Pruc, Przewiężlikowska 2007).
} 
achievement and maintenance of high-quality natural environment and landscape values, as well as prevent landscape fragmentation.

\section{Ecological Network designation methods in Poland}

In Poland, since the 1970s, a few concepts of the ecological network designation were proposed. As stated by Kistowski (2009), none of them did include sufficiently a broad range of criteria that would allow to declare it as universal and apply to all drawn up national documents. Amongst the most significant conceptions of delimiting the ecological network outline (or its element), the following may be mentioned:

- $\quad$ ecological System of Protected Areas - ESOCh;

- the concept of ecological network ECONET-PL;

- the concept of ecological corridors linking mainly Natura 2000 sites;

- a project of ecological corridors linking the European Natura 2000 network - the migration corridors of large mammals;

- the concept of determination and implementation of the PEEN.

As Kistowski (2009) pointed out, the development of ecological network is becoming more sophisticated in Poland. However, there is still need to conduct it further, in order to determine and apply the network in planning and spatially strategic documents, as in the National Spatial Development Concept (Kistowski, 2009).

ESOCh was based on the island biogeographic theory, the theory of patches and ecological corridors, ecotones landscape network research and work in the field of protection and strengthen the cohesion of ecological landscapes. The delineation of the ecological network was based on the following aspects: (1) areas should be characterised by the extent and cohesion for biodiversity protection and ecological stability; (2) should be a natural vast complex (exception being smaller ecosystems located close to each other linked by ecotone broad zones or neighbours ecosystems representing different types of habitats and biocenosis); (3) the emergence of regional protected complex instead of delimitation of small isolated protected areas; (4) aggregation of similar to each other ecosystems and protected areas (the exceptions being the river valleys and similar corridors, for which the streaked system is preferred); (5) connecting the ecosystems and protected areas by ecological corridors instead of their isolation; (6) compact shape of the ecosystem (the exceptions being the developed ecotones systems - i.e. the littoral zone of the lake, and protected areas) (Chmielewski, Kolejko, 2014).

The ECONET-PL network was developed in the cartographic form in scale of 1:500,000, based on the natural valorisation of the landscape and the occurrence of endangered species and ecosystems, including documentation of nature. The established networks, according to the definition, consisted of the node areas and corridors (rank domestic and international). Node areas were determined based on the following criteria: (1) low-intensity farming, determined by the degree of naturalness or semi-natural systems; (2) diversity of habitats, species and forms of use; (3) uniqueness of forms, habitats and species (occurrence of endemic species, relicts, species endangered in Europe); and (4) the size of areas, determining sustainable conservation of biodiversity and landscape. 
Ecological corridors have been drawn based on the compliance of habitats corridors with the core areas, the distribution of natural systems corridor (river valleys, meltwater, mountain chain) and spatial differentiation of land use structure. Attention was also paid to the consistency of the system, which condition the length and width of the corridors.

As a result, 78 core areas- 46 international and 32 domestic, representing $31 \%$ of the landscape area - and 110 ecological corridors - 38 international and 72 national, representing $15 \%$ of the landscape area - were marked (Fig. 2). The ECONET-PL network was the same in $46 \%$ of Polish territory (Liro, 1998).

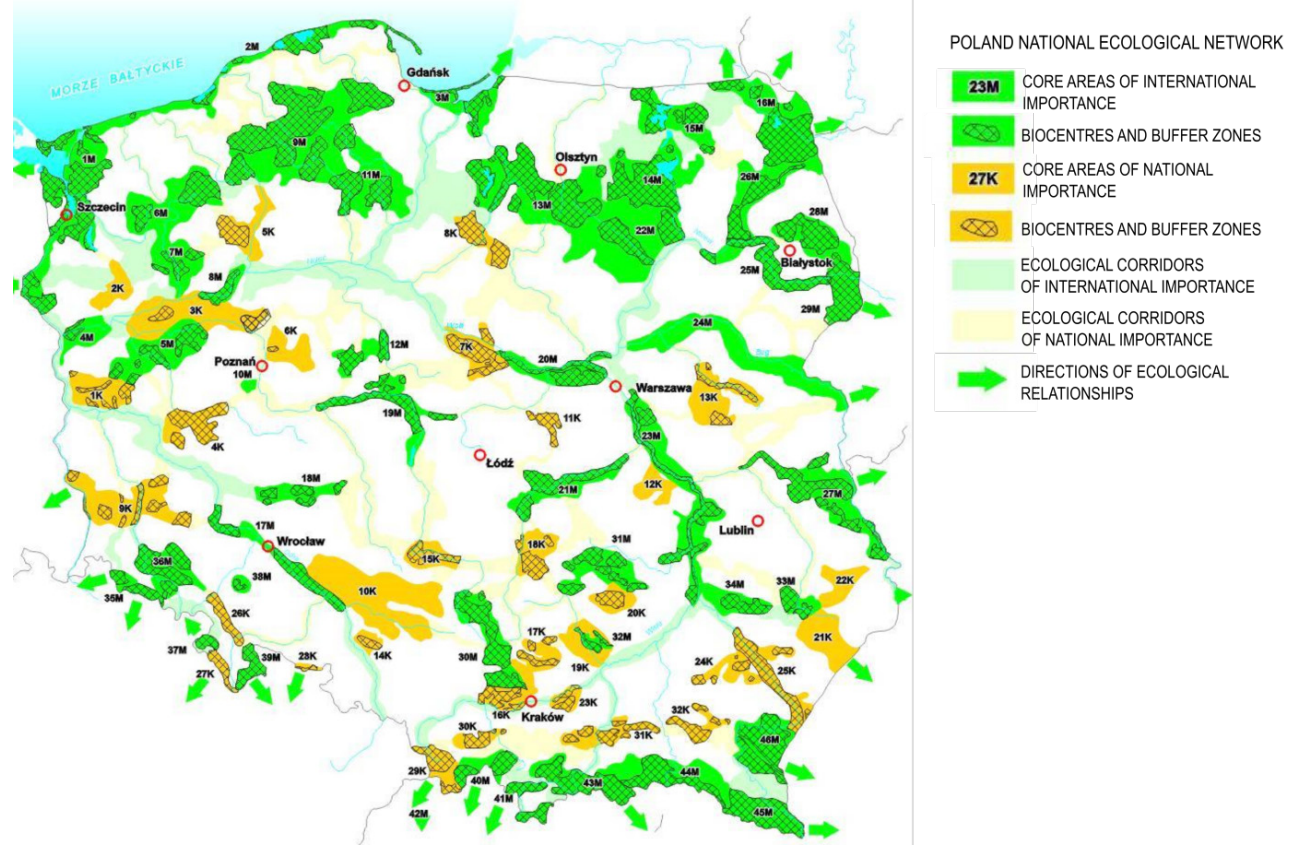

Fig. 2. Ecological network in Poland.

Source based on Koncepcja krajowej sieci ekologicznej ECONET - Polska (The concept of a national ecological network); collective work edited by Anna Liro.

The concept of ecological corridors linking areas of the Natura 2000 network allows for delimitation of areas, which ensures the appropriate conditions for the migration of species to preserve natural biodiversity. Delimitation of ecological corridors is made in two ways: functional (migratory) and structural (stabilizing). Migratory approach allows for delimitation of ecological corridors according to the instantiated set of plants and animals taxa. The basic criterion for determining the corridors is a functionality associated with patency. This means that the ecological corridor is delineated based on the individual sets of attributes, which could not be a barrier or contain significant barriers to the movement of the species. In this approach, the success of migra- 
tory species and patency of linear structures of the landscape is very important. The fundamental importance for structural approach is stabilising the role of the corridor, which regulates the ecological conditions of the areas adjacent to the corridor, which is determined by the structural properties of its construction. Thus, compact and internally differentiated corridors are determined based on the biocenotic and abiotic conditions (Badora, Nowak, 2004).

The project of ecological corridors linking the European Natura 2000 network assumed ensuring the ecological coherence of the Natura 2000 network and other protected areas in the landscape. This project was implemented in 2005 on the order of the Minister of the Environment under the direction of Jędrzejewski. Its updating and detailing were carried out in 2009-2010. The project was set coherent network covering all important natural areas (representing node areas) and ecological corridors. Therefore, the network was called as network of ecological corridors.

Node areas were established as the areas protected by law, that is, National parks, landscape parks, Natura 2000 sites, some nature reserves and protected landscape areas and large forests, river valleys and other areas well preserved in terms of nature, fulfilling an important ecological functions). Corridors destination points located in the border area and important natural areas having ecological connectivity with other important natural areas of neighbouring countries were chosen sequentially. Then environmental analysis that was designed to combine the core areas with the endpoints was conducted and thus ecological corridors were determined.

Ecological corridors were determined based on the following aspects: (1) the existing continuity of areas with a higher degree of naturalness (mainly forest cover), (2) low-density development and (3) selected species indicators (mainly wolf, lynx, elk and deer), which allowed to include the reconstructed location of migration routes of wolf and lynx or analysis of wolf environmental selectivity, as well as the results of genetic testing on the wolf and the earlier results of work on the network (ECONET-PL or other projects of ecological corridors based on different indicator species).

The research led to the delimitation of the seven major corridors (Fig. 3), whose role is to preserve habitat connectivity on an international scale, that is, the Northern Corridor, North Central, West, East, South, Carpathian (Jakimiuk, 2011).

PEEN is based on existing initiatives and European Directives, in which Natura 2000 (SPAs under Birds Directive and SAC under the Habitats Directive) and the Emerald Network, the equivalent to the Natura 2000 network in non-EU countries, became the backbone (JonesWalters, 2007). Cartographic solutions are used to create an indicative map of the PEEN in accordance with the guidelines for different parts of Europe: Central-Eastern called PEEN-CEE, South-eastern Europe (PEEN-SEE) and Western Europe (PEEN-WE). Poland was in the group of Central and Eastern Europe (PEEN-CEE). According to that method, an ecological network should consist of the following elements: core areas (biocentres), corridors, buffer areas and nature restoration areas. The pan European networks maps were developed at scale of 1:3,000,000, which presented two types of analysis: (1) the analysis of habitats and (2) the analysis of species requirements in relation to habitat quality, extent and size, which were integrated in the final stage. The database for analysis was CORINE Land cover 2000 (for the EU countries and candidates), which was other than for PEEN-SEE or PEEN-WE. They have showed that three categories for habitat size are needed for population survival (the marginal size has to be $100 \%$ greater than five times population size). PEEN's maps also present existing protected areas (i.e. Natura 2000, 


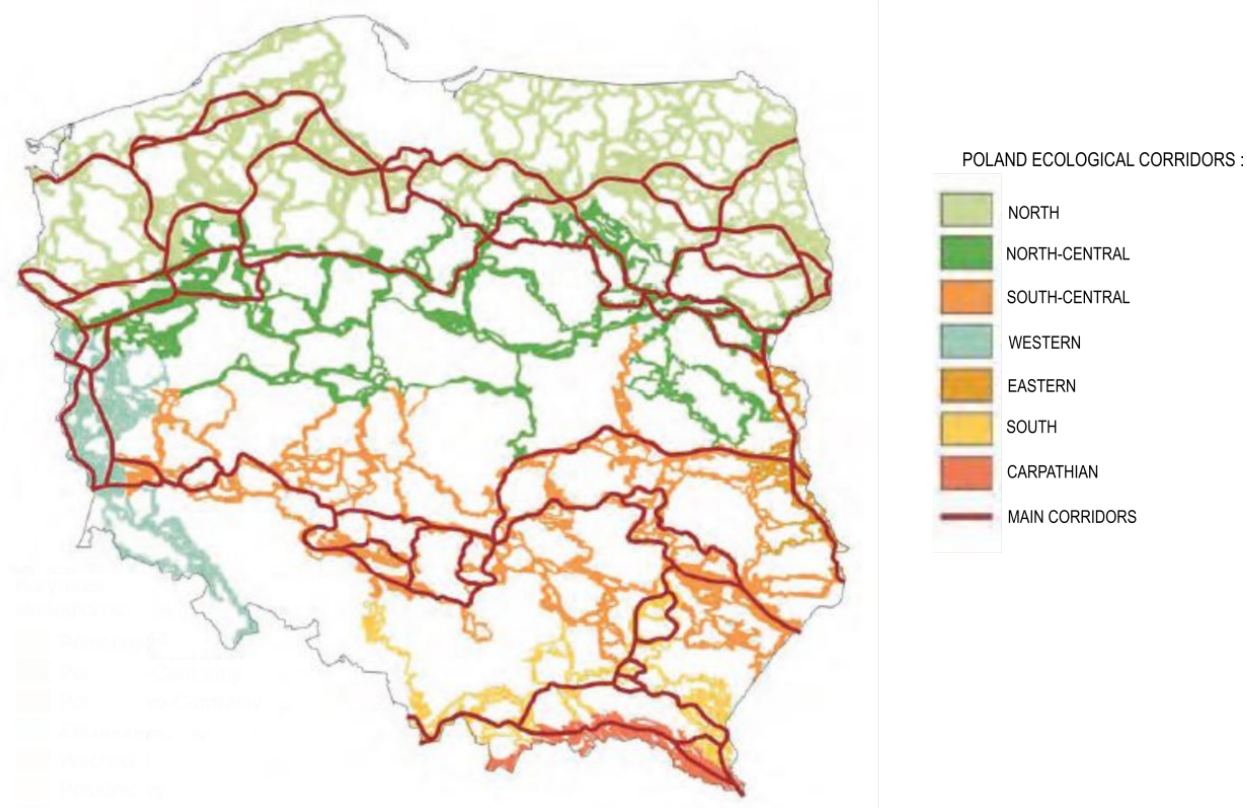

Fig. 3. The course of the main corridors and zoning corridors.

Source based on Plan udrażniania północnego i karpackiego korytarza ekologicznego w czterech wybranych miejscach (Plan of restoring patency the North and the Carpathian ecological corridor in four selected locations) edited by Jakimiuk (2011).

important sites, ecological coherence etc.) and ecological corridors: forested corridors and river and wetland corridors. All maps were consulted with regional experts. The proposed and implemented methodic shows that all maps are comparable (Jongman et al., 2011).

\section{Discussion}

In both countries, considerable attention is paid to the creation of ecological networks. Both countries have adopted their own concepts of ecological networks or have applied European concepts. The approaches to the creation of the ecological networks in individual countries are different (Nowicki et al., 1996; Buček, Lacina, 2000). The networks have been created with the purpose of different function in landscape. From this aspect, we can divide the European approaches into two basic groups:

- conservational-biological approach,

- eco-stabilising approach.

The conservational-biological approach means that the main purpose of creating networks has been ensuring the survival of different species and ecosystems whilst they are fragmented, dispersed and threatened in the landscape. Eco-stabilising approach of creating ecological network is oriented to stabilisation of the whole landscape by a functional zoning of landscape elements 
into ecological compensative areas that compensates zones of intensive land use. Eco-stabilising approach dominates mostly in the Central and Eastern European countries (e.g. Czech Republic, Slovakia, Estonia, Lithuania, Russia and Poland) and conservational-biological approach in the Western Europe (Netherland, United Kingdom, Spain, Denmark, Belgium, Italy, etc.).

ECONNET and the NATURA 2000 concept were applied in both countries. First European concept of a coherent network of protected areas appeared in Poland in the 1970s of the twentieth century. This concept was a result of cooperation between spatial planners and ecologists. This network was called the Ecological System of Protected Areas (pol. Ekologiczny System Obszarów Chronionych - ESOCh), according to which the protected areas of the country should be a system of interrelated areas with varying levels of protection and defined regime of economic activity, including diverse ecosystems and larger under-ecosystems functional units of nature (physiocenoses). The concept emphasised the need for the creation and protection of ecological corridors and ensured better conditions for the functioning of landscape natural systems. Polish approach became interested for Dutch researchers, who in 1991 elaborated the concept of the EECONET (Chmielewski, Kolejko, 2014). In Slovakia, the concept of ecological networks began later, the first signs were in 1985 but a more comprehensive concept was adopted only in 1992. It was a result of long-time effort of Slovak landscape ecologists to prepare landscape-ecological tool as a support to solve landscape-ecological problems. Both schools (Slovak and Polish) have been influenced by European and global activities in this area, such as EECONET and Organic Corridors of America.

When creating ecological networks, greater emphasis was stressed on the construction of corridors in Poland and on the construction of biocentres in Slovakia. An important part of the TSES in Slovakia was a system of ecostabilisation measures aimed at ensuring the spatial stability of the territory as well as ensuring the effective utilisation of the natural resources of the area. Concept of TSES changes the 'classic' idea of the nature conservation based on the division of the landscape to protected and non-protected areas towards a system that maintains the ecological stability of the whole territory by an ecologically suitable spatial structure of the landscape even in the case that it is exploited in different - even in intensive - way. Thus the concept of the TSES is an important

T a b l e 1. Positive and negative factors of the creation of EN in Slovakia.

\begin{tabular}{|l|l|}
\hline Positive factors - strengths & Negative factors - weaknesses \\
\hline Concept of the protection on the total area & $\begin{array}{l}\text { Many concepts and initiatives in nature conservation - } \\
\text { TSES, ECONNET, Natura 2000 }\end{array}$ \\
\hline Inclusion of eco-stabilising measures & Disharmony of individual concepts \\
\hline $\begin{array}{l}\text { Legislative support for the creation of ecological net- } \\
\text { works }\end{array}$ & Formal processing of documentation \\
\hline $\begin{array}{l}\text { Processing of TSES for Slovakia, RTSES for all district } \\
\text { of Slovakia }\end{array}$ & $\begin{array}{l}\text { Disharmony between the elements of the TSES at the } \\
\text { borders of the regions }\end{array}$ \\
\hline $\begin{array}{l}\text { Incorporation of biocentres and biocorridors into spa- } \\
\text { tial planning processes }\end{array}$ & $\begin{array}{l}\text { Insufficient application of the landscape-ecological } \\
\text { regulatives to spatial planning processes }\end{array}$ \\
\hline Application of European initiatives - concepts & Elaboration of documents by amateurs. \\
\hline New efforts for harmonisation of concepts & $\begin{array}{l}\text { Weak implementation of the elements (biocentres and } \\
\text { biocorridors) of the TSES in real practice }\end{array}$ \\
\hline
\end{tabular}


tool to secure spatial stability of landscape (Miklós, 1996). The main positive and negative aspects of the creation of econetworks in both countries are presented in Tables 1 and 2.

T a b l e 2. Positive and negative factors of the creation of EN in Poland.

\begin{tabular}{|l|l|}
\hline Positive factors - strengths & Negative factors - weaknesses \\
\hline $\begin{array}{l}\text { Ecological network is still presented and appeared in } \\
\text { studies or documents of land management and devel- } \\
\text { opment }\end{array}$ & $\begin{array}{l}\text { Many concepts and initiatives in nature conservation - } \\
\text { ESOCh, ECONET-PL, ECONNET, PEEN, Natura 2000 }\end{array}$ \\
\hline $\begin{array}{l}\text { Ecological network is also used to develop other sys- } \\
\text { tems of nature protection at national and regional level }\end{array}$ & $\begin{array}{l}\text { Polish implementation of ecological network still re- } \\
\text { quires additional adaptation }\end{array}$ \\
\hline $\begin{array}{l}\text { Over } 40 \% \text { of country area was included in ecological } \\
\text { network, which contained } 78 \text { core areas (30\% of the } \\
\text { country area) connected by a network of ecological } \\
\text { corridors }\end{array}$ & $\begin{array}{l}\text { Only the ecological corridor has official definition in } \\
\text { Polish Law (Act of the Protection of Nature). There is } \\
\text { lack of definitions for system of ecological corridors or } \\
\text { ecological network in Polish Law. }\end{array}$ \\
\hline $\begin{array}{l}\text { A lot of corridors (almost 60\%) coincided with pro- } \\
\text { tected areas }\end{array}$ & $\begin{array}{l}\text { Despite of official definition of ecological corridor, it is } \\
\text { not legally protected form (unless it is coincided with } \\
\text { protected areas). }\end{array}$ \\
\hline $\begin{array}{l}\text { Ecological network is included into strategic or urban } \\
\text { planning documents at country or regional level }\end{array}$ & $\begin{array}{l}\text { There is no certainty that EN would be included into } \\
\text { spatial planning documents prepared at local level } \\
\text { (which are the basic of urban planning development in } \\
\text { Poland) }\end{array}$ \\
\hline
\end{tabular}

\section{Conclusion}

There are a large number of initiatives that protect biodiversity and create ecological networks, but in real practice, it still does not indicate a positive effect, as shown by the statistics. Up to $60 \%$ of the world's ecosystems are degraded and exploited unsustainably, and only $17 \%$ of habitats and species and $11 \%$ of key ecosystems protected under the European legislation are in good condition. This unfavourable situation is also present in Slovakia. Vulnerability of higher plants reaches 42.6\% (for all threatened categories) and 30.3\% (in CR, EN and VU categories). The vulnerability of invertebrates in the SR is currently around $8.4 \%$ (and 5.4\% only within CR, EN and VU categories). Up to $59 \%$ of vertebrates are at risk (and 23.5\% within CR, EN and VU categories) (Ministry of Environment SR, 2016). This is also the case in Poland. Poland can be characterised by about 10,000 algae species (where circa 2\% - 209 species - are classified as extinct and endangered, vulnerable, rare) and 2,300 of vascular plants species (where 384 species, which is $17 \%$, are classified as extinct and endangered, vulnerable, rare). Up to $27 \%$ of 474 vertebrates are at risk (and $13 \%$ within CR, EN and VU categories; Wróblewska, Olszańska, 2003). If we want to stop these negative trends, we must urgently take action for an effective protection of biodiversity - not only in research but also in real practice.

Subsequently, it has been noted that activities for a nature and environment protection policy have been undertaken by each country and were insufficient, given the scale of growing threats. The causes of the ineffectiveness of the policy and activities to protect nature was sought in (1) lack of adequate integration of biodiversity protection with sustainable development principles; 
(2) inconsistent legal-economic conditions; (3) failure to reach agreement between countries in the aspects of principles, objectives, forms of protection and the activities undertaken for the benefit of species loss and ecological systems of transnational distribution; (4) the occurrence of isolated protected areas; (5) fragmentation of protected areas; (6) inadequate public support, low environmental awareness and lack of active participation in efforts to protect wildlife and the natural environment in society (Liro, 1998). In view of the improvement of the situation, it is necessary to proceed urgently to a coordinated and effective protection of nature and landscape based on the unified system of ecological network building in the form of green infrastructure. Attention should be paid not only to the processing of documents but also to the practical implementation of green infrastructure - the protection and revitalisation of biocentres and bio-corridors. The application of eco-stabilising measures in real practice is also a necessity.

Therefore, the ecological network is one of the concepts that could be a response for environmental management and protection. As with any concept implementation, there could appear some problems. Thereby, we could mention about advantages and disadvantages of ecological network implementation in each country.

\section{Acknowledgements}

This work was supported by the Project VEGA n. 2/0066/15 'Green Infrastructure of Slovakia’.

\section{References}

Badora, K. \& Nowak A. (2004). Spatial structure of the landscape of the ecological corridor of the Odra Valley in the western part of the Opole Province (in Polish). In A. Ciszewska (Ed.), Płaty i korytarze jako elementy struktury krajobrazu - możliwości i ograniczenia koncepcji (pp. 143-154). Warszawa: Problemy Ekologii Krajobrazu.

Bernatek, A. (2011). Assessment of the implementation of ecological corridor concepts in spatial development plans of voivodships (in Polish). Kraków: WWF Polska.

Buček, A. \& Lacina J. (2000). Geobiocenologie II. Brno: MZLU Brno. Chmielewski, T.J. (2009). The Future of the National Ecological System in Poland (in Polish). Problemy Ekorozwoju - Problems of Sustainable Development, 4(2), 73-82.

Chmielewski, T.J. \& Kolejko M. (2014). Problems of protected areas network management in the aspect of ecological connectivity conservation in Poland (in Polish). In Z. Mirek \& A. Nikel (Eds.), Ochrona przyrody w Polsce wobec wspótczesnych wyzwań cywilizacyjnych (pp. 49-64). Kraków : Komitet Ochrony Przyrody Polskiej Akademii Nauk.

De Montis, A., Caschili, S., Mulas, M., Modica, G., Ganciu, A., Bardi, A., Ledda, A., Dessena, L., Laudari, L. \& Fichera C.R. (2016). Urban - rural ecological networks for landscape planning. Land Use Policy, 50, 312-327. DOI: 10.1016/j. landusepol.2015.10.004.

Gerlée, A. (2010) Protection of ecological corridors in development strategies and spatial development plans of voivodships (in Polish). In III Konferencja Geografów-Doktorantów (pp. 49-61). 10-11 October 2008. Wydawnictwo pokonferencyjne. Warszawa: WGiSR UW.

Hüse, B. Szabó, Sz., Deák, B. \& Tóthmérész B. (2016). Mapping an ecological network of green habitat patches and their role in maintaining urban biodiversity in and around Debrecen city (Eastern Hungary). Land Use Policy, 57, 574-581. DOI: 10.1016/j.landusepol.2016.06.026.

Izakovičová, Z., Hrnčiarová, T., Miklós, L., Tremboš, P., Ružičková, J., Liška, M., Králik, J., Moyzeová, M., Šíbl, J. \& Pauditšová E. (2000). Methodology for elaboration of the projects territorial systems of ecological stability (in Slovak). Združenie Krajina 21. Bratislava: MŽP SR.

Izakovičová, Z. \& Miklós L. (2010). The concept of the territorial system of ecological stability (TSES) in the planning practice in Slovakia. In Gy. Fábos, R.L. Ryan, M. Lindhult, P. Kumble, L. Kollányi, J. Ahern \& S. Jombach (Eds.), Proceedings of Fábos Conference on Landscape and Greenway Planning 2010 (pp. 252-259). Budapest: Corvinus University of Budapest, University of Massachusetts Amherst.

Jakimiuk, S. (Ed.) (2011). The plan of unblocking of the north and the Carpathian ecological corridor in four selected loca- 
tions. Study carried out within the framework of the project "Protection of species of lynx, wolf and bear in Poland (in Polish). Białowieża -Warszawa: WWF Polska.

Jones-Walters, L. (2007). Pan-European Ecological Networks. J. Nat. Conserv., 15, 262-264. DOI: 10.1016/j.jnc.2007.10.001. Jongman, R.H.G. (1996). Research priorities: scientific concepts and criteria. In Perspectives on ecological networks (pp. 151-160). European Centre for Nature Conservation, series Man and Nature, 1(14). Tilburg.

Jongman, R.H.G. (2008). Ecological networks, from concept to implementation. In S.K. Hong, N. Nakagoshi, B. Fu \& Y. Morimoto (Eds.), Landscape ecological applications in man-influenced areas (pp. 57-69). Dordrecht: Springer. DOI: 10.1007/1-4020-5488-2_4.

Jongman, R.H.G., Bouwma, I.M., Griffioen, A., Jones-Walters, L. \& Van Doorn A.M. (2011). The pan European ecological network: PEEN. Landsc. Ecol., 26(3), 311-326. DOI: 10.1007/s10980-010-9567-x.

Kistowski, M. (2009). Ecological corridors in environmental assessments of national and regional spatial planning plans (in Polish). In W. Jędrzejewski \& D. Ławreszuk (Eds.), Ochrona łączności ekologicznej w Polsce (pp. 233-239). Materiały z konferencji międzynarodowa "Wdrażanie koncepcji korytarzy ekologicznych w Polsce". Białowieża: Zakład Badania Ssaków Polskiej Akademii Nauk.

Kwartnik-Pruc, A. \& Przewięźlikowska A. (2007). Comparison of the functioning of spatial planning in Poland and Germany (in Polish). Geomatics and Environmental Engineering, 1(3), 149-160.

Liro, A. (Ed.) (1998). Strategy for implementation of the national ecological network, ECONET-POLSKA (in Polish). Warszawa: Fundacja IUCN Poland.

Louka, E. (2004). Conflict integration: The environmental low of the European Union. Anwerp, Oxford, New York: Intersentia.

Lőw, J. et al. (1984). Principles for defining and designing a territorial system of ecological stability in territorial projection practice (in Czech). Brno: Agroprojekt.

Miklós, L. et al. (1985). Ecological general ČSSR: part SSR - spatial differentiation. Bratislava: ÚEBE CBEB SAV.

Miklós, L. (1991). Principles of the Slovak environmental policy. Životné Prostredie, 25, 174-178.

Miklós, L. (1996). The concept of the territorial system of ecological stability in Slovakia. In R.H.G. Jongmann (Ed.), Ecological and landscape consequences of land use change in Europe. Man and Nature, 2, 385-406.

Miklós, L., Izakovičová, Z. et al. (2006). Atlas of representative geoecosystems of Slovakia. Bratislava: ÚKE SAV, Bratislava: MŽP SR

Ministry of Environment (2016). Environmental status report of the Slovakia. Bratislava: MŽP SR.

Monitor Polski Nr. 26, Poz. 432 (2011). The notice of the President of the Council of Ministers of 26 July 2001, for the announcement of the Concept of spatial development of the country (in Polish).

Muchová, Z. \& Petrovič F. (2010). Changes in the landscape due to land consolidations. Ekológia (Bratislava), 29(2), 140-157. DOI: 10.4149/ekol_2010_02_140.

Nowicki, P., Bennet, G., Middleton, D., Rientjes, S. \& Wolters R. (Eds.) (1996). Perspectives on ecological networks. European Centre for Nature Conservation, series Man and Nature, 1, 192.

Pauditšová, E. (2010). Miestny územný systém ekologickej stability v projektoch pozemkových úprav. In Krajinné plánovanie (pp. 281-286 + mapy). Bratislava: STU.

Pawłat-Zawrzykraj, A. \& Brzank M. (2013). Continuity of spatial management of a commune in terms of building up its ecological network on the example of the Góra Kalwaria Commune (in Polish). Przeglad Naukowy - Inzynieria $i$ Ksztaltowanie Środowiska, 22(4), 402-412.

Reháčková, T. \& Pauditšová E. (2008). Vegetácia v urbánnom prostredí. Bratislava: Cicero.

Rozenau-Rybowicz, A. \& Baranowska-Janota M. (2007). Ecological corridors in spatial planning (in Polish). In Problemy rozwoju miast. Kwartalnik Naukowy (pp. 132-142). Kraków: Instytut Rozwoju Miast.

Ružička, M. \& Miklós L. (1982). Landcape-ecological planning (LANDEP) in the process of territorial planning. Ekológia (ČSSR), 1, 297-312.

Szulczewska, B. (2004). Spatial planning as an instrument of ecological networks implementation: in between the theory and practice (in Polish). In A. Ciszewska (Ed.), Płaty i korytarze jako elementy struktury krajobrazu - możliwości $i$ ograniczenia koncepcji (pp. 54-62). Warszawa: Problemy Ekologii Krajobrazu.

Van der Sluis, T., Buijs, J., Koopmanschap, E., Gosselink J.M.J., Kliuiev, V. \& van Eupen M. (2011). Development of an ECONET for Lugansk Oblast. Rural development and sustainable development in Ukraine. Alterra report 2153.a. Wageningen: Alterra.

Wojciechowski, K. (2004). Implementation of ecological corridors concept (in Polish). In A. Ciszewska (Ed.), Płaty i korytarze jako elementy struktury krajobrazu - możliwości i ograniczenia koncepcji (pp. 221-228). Warszawa: Problemy Ekologii Krajobrazu.

Wróblewska, D. \& Olszańska A. (2003). Przyroda. In Inspekcja Ochrony Środowiska, Raport. Stan Środowiska $w$ Polsce $w$ latach 1996-2001 (pp. 177-184). Warszawa. 